\title{
基于核心素养背景下的引导式教学—— “基因突变”为例
}

\author{
韩圭范曾丽
}

西华师范大学生命科学学院

DOI:10.32629/er.v3i2.2514

[摘 要] 如今,指向核心素养的中学生物教材变革与教学改革正在如火如茶地进行。但仍有许多教师按照以教师教为主的传统教学模式开展课 堂, 在教学目标的达成上依然遵循知识、能力、情感态度价值观的三维目标。基于核心素养背景, 本文以 “基因突变” 为例, 通过游戏环节、文 本分析、合作讨论等活动,对以学生为主体的引导式教学进行深入探讨。

[关键词] 基因突变; 太空育种; 引导

“基因突变” 选自人教版高中生物必修 2 第 5 章第一节《基因突变和基 因重组》, 是高中生物教学中的重要内容, 是对 “变异” 知识的拓展延伸, 也是学生学习 “生物的进化” 的基础。在本节内容的教学中, 教师往往不 注重基因突变概念、诱因、特点之间的联系 ${ }^{[1]}$, 将零散的知识点灌输给学 生, 课堂气氛死板, 学生参与度不高, 加上教学内容较多, 学生无法深入理 解记忆知识点, 多靠死记硬背。因此, 如何寻找各个知识点之间的联系并通 过一两个实例贯穿全文是值得教师思考的问题, 如何基于核心素养背景下 开展引导式教学 ${ }^{[2]}$, 让学生一步步深入挖掘、自主学习是完成本节课的关 键点。本文以 “基因突变” 的教学片段为例, 在课堂教学中通过问题串的 形式, 以镰刀型细胞贫血症和太空育种等实例贯穿全文, 环环紧扣, 步步加 深, 使学生紧跟教师步伐, 顺理成章地掌握知识。在课堂中既设置有游戏环 节, 又有小组讨论, 以期能够打破传统教学模式, 将课堂充分交给学生, 让 学生在教师的引导下, 在思考、理解的基础上完成对核心素养的内在转化。

\section{1 教学目标}

1. 1 生命观念

能够在较好地理解基因突变概念的基础上,列举基因突变的实例, 形 成结构与功能观、进化与适应观。

1. 2 科学思维

能够对文字材料进行归纳与概括, 解释引起镰刀型细胞贫血症的根本 原因, 运用辩证的思维去看待基因突变。

1. 3 科学探究

积极参与课堂游戏和对社会性问题的讨论, 在游戏和讨论的过程中互 帮互助, 学会合作。

1. 4 社会责任

积极运用基因突变的概念、特点及诱因等知识解决人们对太空食品安 全性问题的困惑。

\section{2 引入}

教师展示自己家人的全家福, 描述家人特征并通过一系列有联系的问 题带领学生参与课堂, 活跃课堂氛围。

其中 “女儿都继承了父亲的弯眉毛和短额头” 属于遗传, “女儿与父 母以及姐妹不完全一样” 称为变异, 而 “由于玩手机、长期謷夜所导致的 眼睛变小”属于不可遗传变异, 由此引入主题“可遗传变异一一基因突变”。

设计意图: 高中课堂较为沉闪, 学生的情绪体验较初中阶段强烈 ${ }^{[3]}$, 兴 趣范围更广。教师现身说法, 利用自己的全家福引起学生好奇, 通过问题串 步步深入, 复习旧知, 引入新知。

\section{3 游戏活动, 构建概念, 深化理解}

教师设置游戏活动, 引导学生理解并自主概括出基因突变的概念:

学生 4 人为一小组, $1 、 2$ 号代表DNA双链, 3 号代表mRNA, 4 号代表蛋白质。
游戏规则为:（1) 30秒：1号记住PPT上的碱基序列, 2 号记住它的互补链, 其他人不能偷看。（2)第二个 30 秒：1、2号相互核对, 由 2 号将自己的碱基 序列传递给 3 号。(3) 3 号同学以该DNA单链为模板, 通过碱基互补配对原则, 写出mRNA碱基序列并传递给 4 号。(4) 4 号查阅教材 (人教版) 67 页的密码子 表, 翻译出相应的蛋白质。游戏完成后由每组的 3 号同学将该组的DNA模板 链的碱基序列、RNA的碱基序列及相应的蛋白质写在黑板上。

学生对照PPT上给定的模板检查每小组书写的序列, 见图1。首先会发 现蛋白质的种类不同, 往前推找到根本原因, 得出概念中的 “DNA分子上的 碱基” 发生了改变。接着学生观察每个小组写出的DNA模板链, 得到碱基发 生了替换和缺失的变化, 教师需要补充 “增添” 这一情况。

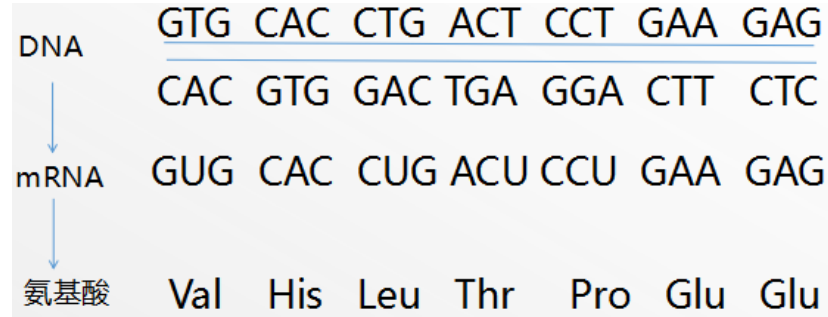

图1 人体血细胞中血红蛋白基因的部分碱基序列

教师接着追问: 当DNA分子中发生碱基替换、增添、缺失时, 就能引起 基因突变吗? 学生思考时, 教师提示: 基因是具有遗传效应的DNA片段。因 此, 当DNA分子上非遗传片段碱基序列改变时, 不是基因突变。综合以上, 得出基因突变的准确概念。

既然基因突变是由于DNA分子中的碱基发生改变而产生的, 那么基因 突变更容易发生在什么时期？基因突变若发生在配子中或者体细胞中, 能 否传递给后代? 根据概念, 学生很容易联想到与DNA解旋并进行复制相关 的细胞分裂间期, 再回顾有丝分裂和减数分裂的结果, 可以得出若基因突 变发生在配子中能够遗传, 发生在体细胞中不能遗传的结论。

设计意图: 通过自创的游戏环节调动学生参与课堂的热情, 活跃课堂 氛围。游戏体现了复制、转录、翻译的过程, 学生在游戏中找出蛋白质种 类出现差异的根源是 “DNA分子上的碱基”出现了问题。学生通过观察板 书, 总结出 “替换、缺失、增添” 及 “引起基因碱基序列的改变” 等一列 关键词句, 得出基因突变的概念, 同时思考基因突变更容易发生的时期, 深 化理解。

\section{4 层层递进,列举实例}

回看游戏中的碱基序列, 即血红蛋白基因的部分碱基序列 ${ }^{[4]}$, 教师提 出问题: 假设其他碱基都不变, 将编码第6位氨基酸的密码子对应的DNA上 的碱基CTT中的第一个T替换成A会出现什么情况? 则mRNA上的GAA变成GUA, 翻译出的谷氨酸则会变成倾氨酸, 这就导致了镰刀型贫血症。教师通过讲 
解镰刀型细胞贫血症的症状、患者红细胞的形态变化和其在对抗疮疾方面 的优势, 告知学生这是人类在自然选择压力下的进化。教师引导学生思考 镰刀型细胞贫血症的诱因, 翻看教材 83 页基因突变的原因。

设计意图: 通过讲解镰刀型细胞贫血症这一经典的基因突变实例, 从 学生接触的碎片化知识入手, 让学生知道了患镰刀型细胞贫血症的根本原 因和它对疮疾的抗性, 明白事物的两面性, 再回归教材, 寻找诱因。

\section{5 文本分析,提炼关键,概括特点}

有了对基因突变诱因的认识, 教师向学生科普太空育种 ${ }^{[5]}$, 带领学生 根据四则与太空育种相关的材料 (见图2、图3、图4、图5), 总结出基因突 变的特点, 即低频性、随机性、不定向性、多害少利性。再结合结合镰刀 型细胞贫血症、太空育种以及高产青霉菌等实例说明基因突变在生物界是 普遍存在的。

资料一：上世纪50年代至60年代初期，前苏联和美国 的科学家就已开始将植物种子搭载卫星上天，并在返回地 面的种子中发现其染色体畸变频率有较大幅度的增加，但 一般种子突变率是在 $0.05 \%-0.5 \%$ 之间，一点变化都没 有的种子占大多数。

— 《被神话的太空育种》

图2 太空育种资料一

\section{资料二 : 植物幼苗期可能发生基因突变，引起整个植株} 变异; 生长幼芽时期也可能发生基因突变，引起长成的枝 条变异; 生长花芽时期也可能发生基因突变，引起一朵花 表现出变异。

图3太空育种资料二

资料三 : 种子搭载后产生的变异是各种各样的，选择面 非常广，有的会变好，有的会变坏。以小麦种子为例，搭 载后的植株有高秆、矮秆，穗子有大、小，生育期有的提 前、有的推后。像麒磷菊这种花卉，颜色比较单一，一般 为紫红色，让它去太空，它的颜色会变得更加丰富。 —《航天育种助推农作物改良》

图4 太空育种资料三

资料四 : 现在普遍有一种看法，觉得种子只要上天转一 圈回来之后就会变得特别好。其实，在所发生的突变中， 也并非全都是高产、超大、营养丰富、抗病力强等有益变 异。从总体上来看、畸形、低产、抗病能力减弱等不利于 生产的劣性突变表现得更多。

—《被神话的太空育种》

图5 太空育种资料四
教师启发学生结合基因突变的特点、概念和诱因, 小组讨论太空食品 是否安全并给出理由。学生言之有理即可。

设计意图: 新高考背景下生物试卷中有许多文字材料, 尤为强调学生 的归纳概括能力。教师引导学生通过提取、解读关键字词对基因突变的特 点进行概括, 使学生关注社会议题, 利用所学知识对实际问题进行讨论, 作 出理性解释, 学以致用。

\section{6 总结全文,升华思想,辩证思维}

教师带领学生回顾所学知识, 总结出基因突变的意义。

总结提升：虽然基因突变是多害少利的, 但却是不可缺少的。任何事 物的好坏都不是绝对的, 只要我们合理地进行利用, 它就能造福人类!

设计意图: 对教学内容进行概括, 加深学生对基因突变的印象。升华 主题, 让学生用辨证的思维去看待事物。

\section{7 教学反思}

本节课思路清晰, 通过问题串的形式使教学内容环环相扣。首先通过 展示全家福激发学生兴趣, 引发学生对遗传、变异现象的思考, 引入新课; 接着教师通过自创的游戏环节调动学生热情, 引导学生回答 “什么是基因 突变”, 并深入剖析 “基因突变更容易发生在什么时期”, 深化对基因突变 概念的理解; 通过对游戏中DNA模板链上的碱基进行替换, 引出镰刀型细胞 贫血症, 带领学生回归教材找出 “镰刀型细胞贫血症的诱发因素是什么”; 沿着诱因讲解太空育种, 使学生掌握基因突变的特点, 再启发学生根据所 学内容思考 “太空食品是否安全”; 综合上述环节对基因突变的意义进行 概括, 最后教导学生任何事物都具有两面性, 运用辩证的观点看待事物, 升 华思想。

课堂饱满紧凑、详略得当, 实现了《普通高中生物学课程标准 (2107 版)》对该节课的核心素养方面的要求。课堂让学生在玩中学, 学中思, 学 生参与感强, 充分提现了以学生为主体, 教师为主导的引导式教学。本节课 密切联系生活实际, 以科学的思维积极思考社会现实问题, 潜移默化中培 养学生承担社会责任的能力。

\section{[参考文献]}

[1]沈静丹.概念课中创设主线,注重思维训练—— “基因突变”一节的 教学设计[J].中学生物学,2016,32(02):9-11.

[2]郭沝,徐莹, 薛凌云, 等.案例引导式教学在生物化学课程中的应用 [J].教育教学论坛,2018,(27):165-166.

[3]王碧君.对高中生学习障碍的情绪特点的研究 [J]. 读与写(教育教学 刊),2019,16(09):123.

[4]郑长军.浅谈镰刀型细胞贫血症的成因[J].中学生物教学,2015,(24):59.

[5]李谨,耿金鹏,曹天光,等.太空诱变育种的研究进展 [J].北方园 艺,2015,(14):189-193.

作者简介:

韩圭(1996--), 女, 汉族, 四川南充人,西华师范大学在读硕士研究 生,研究方向: 学科教学(生物)。

范曾丽(1981--),女,汉族,四川简阳人,博士,副教授, 研究方向为生 物课程与教学论。 